\title{
The Roman Mosaics of the Roman Villa in the Monumental Complex of Santiago da Guarda, Municipality of Ansião (Portugal)
}

\section{Ansião Belediyesi (Portekiz), Santiago da Guarda Anıtsal Kompleksi'ndeki Roma Villası Mozaikleri}

Rodrigo Marques PEREIRA*

(Received 20 October 2016, accepted after revision10 July 2017)

\begin{abstract}
Classified as a National Monument in 1978, the Palace of Vasconcelos or manor house of the Counts of Castelo Melhor, important museum centre of Ansião Municipality, is a reference property of the noble houses of the sixteenth century, formed by a fifteenth-century tower and sixteenth-century palace.

The monument is located in Santiago da Guarda parish seat of Ansião municipality, in the district of Leiria, and is currently known as the Monumental Complex of Santiago da Guarda.

The need to recover the set was preceded by an archaeological investigation that confirmed the existence of the ruins of a Late Roman villa in the basement, which stand out roman mosaics which are integrated in the respective rehabilitation project.
\end{abstract}

Keywords: Ansião, Santiago da Guarda, Roman villa.

Öz

1978 yılında ulusal anıt olarak tescil edilen Vasconcelos Sarayı ya da Castelo Melhor Kontlarının Köşkü, Ansião Belediyesi için önemli bir müze merkezi olup 15. yüzylla ait bir kuleden şekillendirilmiştir ve 16. yüzyllda saray ve malikane yapılarına güzel bir örnek teşkil etmektedir.

Anıt, Santiago da Guarda'daki Ansião Belediyesi'nin papazllk merkezinde, Leiria Bölgesi’nde yer almakta olup günümüzde Santiago da Guarda Anitsal Kompleksi olarak bilinmektedir.

Kompleksin iyileştirilmesi çalışmalarına arkeolojik olarak temelde bir geç Roma villasının kalıntılarına ulaşılmasından sonra gerek duyulmuş olup bu Roma villasının tabanında tespit edilen mozaik döşemeler de iyileştirme çalışmaları kapsaminda yer almaktadır.

Anahtar Kelimeler: Ansião, Santiago da Guarda, Roma villası.

\section{Context}

Classified as a National Monument in 1978 and owned by the Municipality of Ansião since the last decade of the $20^{\text {th }}$ century, the former palace of Vasconcelos or manor house of the Counts of Castelo Melhor, located in Santiago da Guarda parish seat of Ansião county in the district of Leiria, is a reference property of the noble houses of the $16^{\text {th }}$ century, formed by a $15^{\text {th }}$ century tower and $16^{\text {th }}$ century palace.

\footnotetext{
* Rodrigo Marques Pereira, Archaeologist, Municipality Ansião, Monumental Complex of Santiago da Guarda, Street Condes de Castelo Melhor 3240690 Santiago da Guarda, Portugal. E-mail: rodrigo.pereira@cm-ansiao.pt
} 
The monument was the subject of a rehabilitation process an archaeological intervention took place between 2002 and 2006. This process integrated an archaeological excavation, which took place between 2002 and 2006. In 2012, as part of the redevelopment of its surrounding, it has developed a final campaign of archaeological work.

The Palace of Vasconcelos, an important museum centre of the Municipality of Ansião, currently known as the Monumental Complex of Santiago da Guarda, is open to the public daily.

\section{Archaeological intervention}

The archaeological intervention resulted in the definition of the urban area of a late Roman villa of $4-5^{\text {th }}$ centuries $\mathrm{AD}$, with $1500 \mathrm{~m}^{2}$, where the geomorphological context of the site is according to the descriptions of the Agronomist Roman writer Columella for the implementation of a villa ${ }^{1}$, where were located twentyone polychromatic roman mosaics which are integrated in the building of the restoration project.

The Roman villa of Santiago of the Guard is integrated in the typology of the Villa-Bloc has a composite plan, identified by Jean-Gérard Gorges (1979: 126127). Presents itself as a construction consisting of three architectural sets that make up the villa's unity (peristyle; corridor; private wing). This tripartite model is paralleled in the village of Piazza Armerina, in Sicily, and may have its origins in space organization at the Forum of Trajan in Rome (Gorges 1979: 126-127).

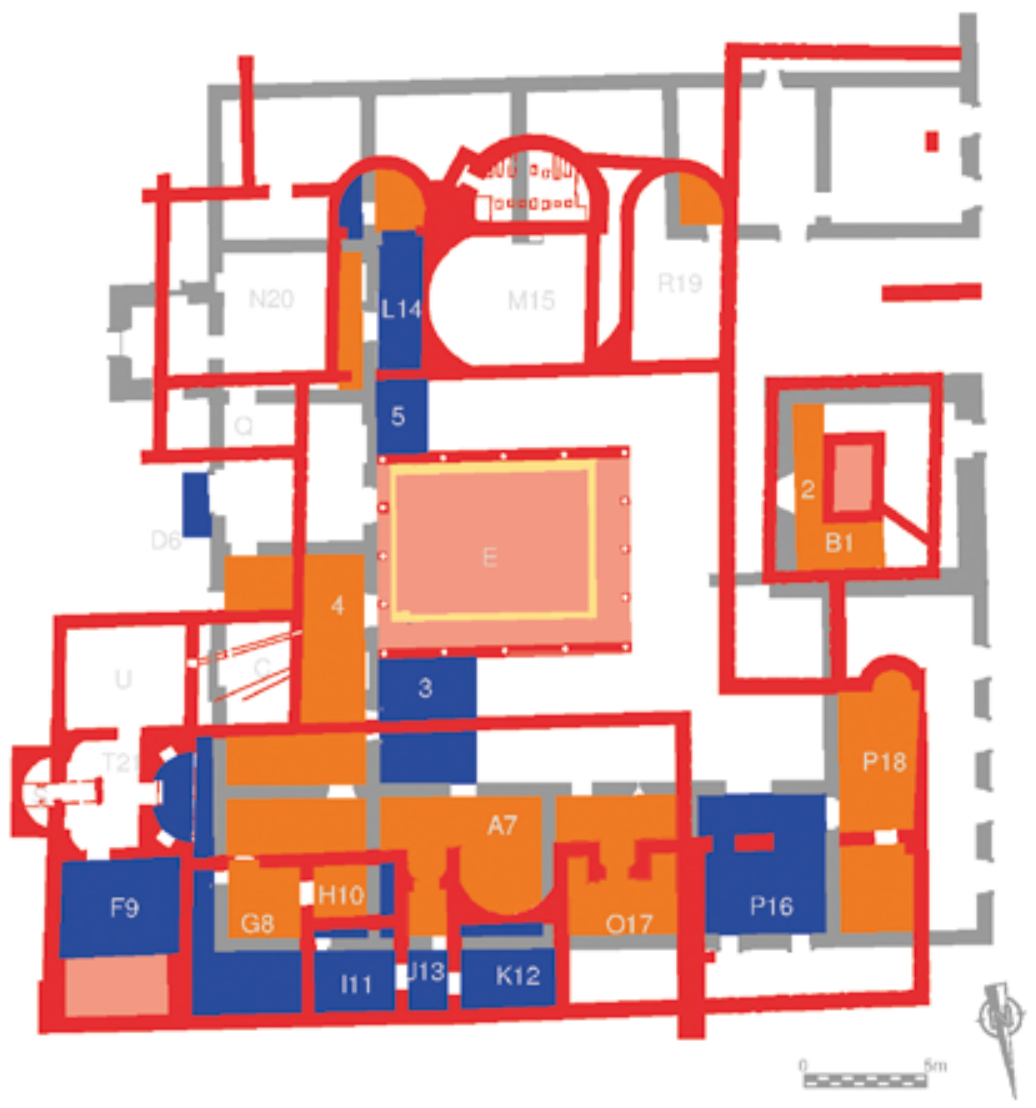

1 Columela, De re rústica, I, 6,1.

\section{Legend:}

- SIXTEENTH-CENTURY PALACE - URBAN AREA OF THE ROMAN VILLA

Visible areas of the mosaics

Areas that are not visibles of the mosaics

- Paved areas with opus signinum

SPACES/MOSAICS (alphanumeric code)

A7 - Corridor

B1/B2 - Entrance hall (atrium - impluvium)

C - Plumbing compartment

D6 - Salon (oecus)

E3/E4/E5 - Peristyle (peristylium)

$\mathrm{Fg} / \mathrm{S} / \mathrm{T} 21 / \mathrm{U}$ - Private baths

G8/H10/I11/K12/O17 - Rooms (cubiculae)

J13 - Corridor

L14/R19 - Support rooms to the dining room

M15 - Dining room (triclinium - hypocaustum/praefurnium)

N 21 - Service area (culina)

P16/18 - Large reception room (exaedra)

Q- Corridor/Storage area (cella) 
The relationship that exists between the entrance hall and the peristyle gives the villa an extraordinarily urban appearance, reproducing the classic Roman domus (Gorges 1979: 126-127; Gros 2001 II: 336-337) (Fig. 1).

Currently it is possible to observe an area of $168 \mathrm{~m}^{2}$ of roman mosaics, a total of $299 \mathrm{~m}^{2}$ that were discovered (Fig. 1).

The urban pars of the roman villa served as the foundation for the $16^{\text {th }}$ century monument, the palace of Vasconcelos.

\section{Mosaics}

\section{Mosaics numbers 1 and 2 (Figure 1)}

Location: In situ. Entrance hall, equipped with a rectangular impluvium of the Roman building, this has served as a foundation to the $15^{\text {th }}$ century tower (Fig. 1).

Description: Polychrome mosaics that paved the portico area of the Roman building and the main entrance (lobby).

Both porticos had an identical decorative pattern, it is possible to observe that the areas north and south of the porticos were decorated with linear garlands of laurel leaves and geometric motifs, whereas, in the areas east and west of the porticos were with peltas tangential, from whose lobes form nodes of Solomon.

Material / colour: Limestone / white, blue-black, light blue, red, pink, yellow.

Dimensions of the floors: North and South $6.30 \mathrm{~m} \mathrm{x} \mathrm{1,90} \mathrm{m;} \mathrm{East} \mathrm{and} \mathrm{West} \mathrm{-} \mathrm{7,}$ $50 \times 1,90 \mathrm{~m}$.

\section{Mosaics numbers 3, 4 and 5 (Figures 1, 2, 3, 4)}

Location: In situ. The rectangular peristyle of the Roman building. It was discovered under the courtyard of the $16^{\text {th }}$ century palace.

Description: Polychrome mosaics paving the north, east and south porticos of the peristyle. In the west area there are no traces of the roman mosaic.

The field of the mosaic in the northern portico is framed by a frame with a braid two strands, whereas the central part present a composition circles constructed from interlaced spindles, simultaneously form star four corners, with moldings decorated with chevrons in rainbow and square positioned alternately. Centred in the composition form part of crosses four corners of concave concentric lozenges (Mosaic 3 - Fig. 2).

On the north side of the east portico the decorative field of the mosaic is framed by a braid of two strands, from which and toward the centre, develops an orthogonal composition forming the mosaic field, consists of squares and lozenges adjacent performed in meander swastikas. The spaces next to the boundary are shown by a filled triangle. This panel has a limit to the north and to a lower level, a rectangular mat with a square alignment and concentric lozenges, with the spaces filled with a concentric triangle (Mosaic 4 - Fig. 3).

The central area of the mosaic is decorated with a figurative panel with a medallion, but it is only possible to see one of the corners of the frame that fits and is enrolled in one of the angles an element of floral origin, a chalice (Mosaic 4 - Fig. 3). 

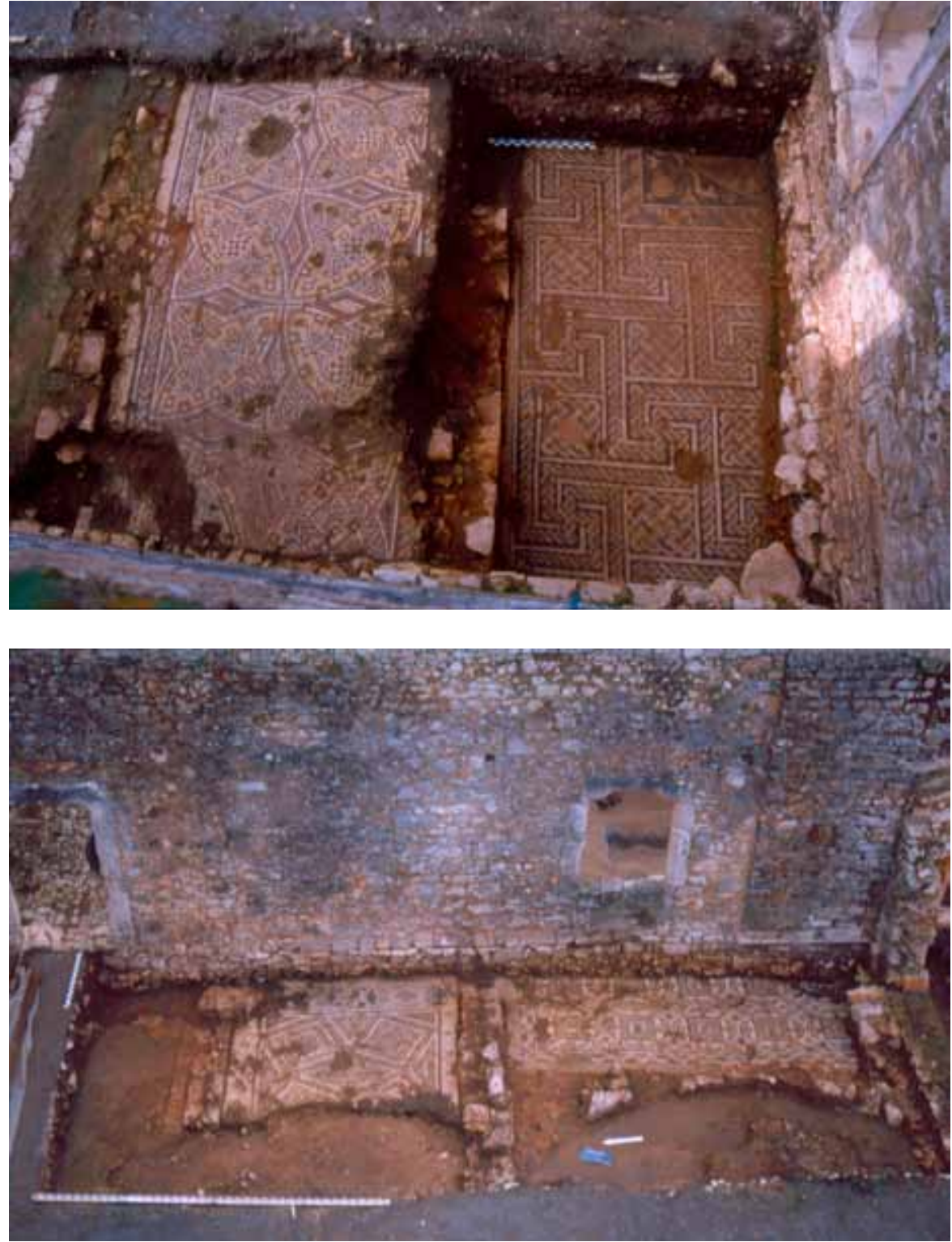

A separate pattern in the east and south porticos, is a rectangular band with the blue-black surround, which are inscribed four peltas with internal spirals at each end, interspersed by two lozenges and concentric square (Mosaic 5 - Fig. 4).

In the south portico, the mosaic field is framed by a white band, filled with florets. The frame of the field consists of a triple thread, the blue-black. The field is decorated by a composition of squares and lozenges formed from a braid of two strands (Mosaic 5 - Fig. 4).

Material / colour: Limestone / white, blue-black, red, pink, yellow.

Dimensions of the floors: North- 10,40 x 2,50 m; East - 14,00 x 3,00 m; South - 10,40 x 3,00 m; West - 14,00 x 3,00 m.

\section{Mosaic number 6 (Figure 1)}

Location: In situ. Space interpreted as receiving room modest environment (oecus) compared with $\mathrm{P}$ space adjoining of the east portico of the peristyle. Only remain two portions of the mosaic, are visible in the east wing of the $16^{\text {th }}$ century palace.
Figure 2

Mosaic of the north portico of the peristyle (at left); Mosaic of the long corridor (at right).

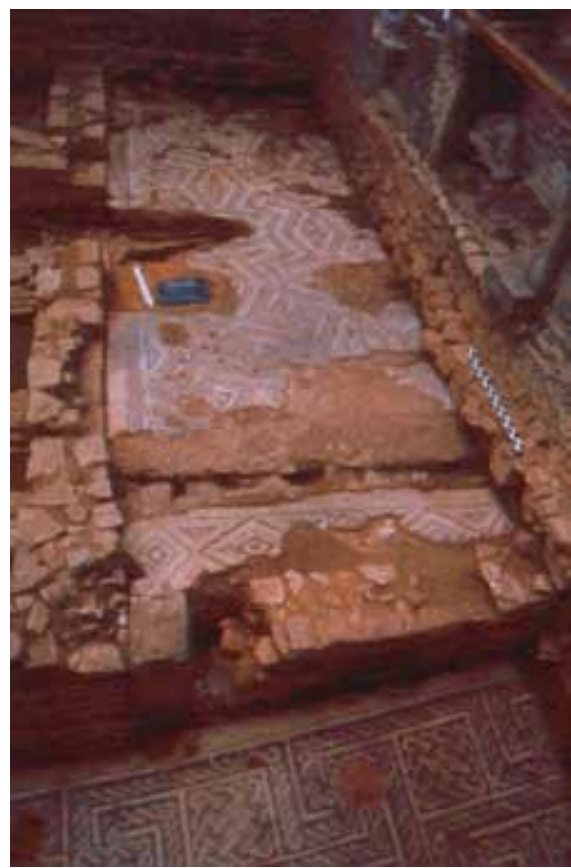

Figure 3 Mosaic of the east portico of the peristyle.

Figure 4

Mosaic of the south portico of the peristyle (at left); Mosaic of the support room to triclinium (at right). 
Description: Polychrome mosaic composed by three distinct decorative pattern. A zone with perimeter strip bordering the mosaic at north and is decorated by a wave of peltas with their apex topped by triangular motif.

What should be the border of the floor decorations is formed by a braid of two strands from which, and in the right side of the carpet, is developed several branches forming the mosaic field decorated with a meander of swastikas.

In the centre is a composition decorated with scales, surrounded by outstanding vegetable nature. Enclosing the central motif there is a perimeter band formed by stars four curvilinear convex tips, adjacent wings, with nodes of Solomon and others motifs inscribed in squares convex curved sides and set the bases of the stars points. Finding this range delimited the centre by a braid of two strands.

Material / colour: Limestone / white, blue-black, red, pink, yellow.

Dimensions of space: undefined x $6,25 \mathrm{~m}$

\section{Mosaic number 7 (Figures 1, 2, 3, 5, 6)}

Location: In situ. Long corridor, located parallel at north portico of the peristyle. The floor is under the courtyard of the $16^{\text {th }}$ century palace.

Description: Polychrome mosaic with five distinct zones with the following decoration, from east to west: to mark the doorway that is located in the apse that allows access to the private spa sector is found inscribed on the floor a rectangular carpet with a frame formed by a braid of two strands.

Between the carpet and the floor boundary there is a line oblong scales, appearing stopped at the intersection zone with that will. The field is comprised of an orthogonal composition triangles and squares, from which emerge star four corners and geometric figures in perspective (parallelepiped). The perimeter band is filled with florets (Fig. 5).

To separate the apse area from the remaining corridor area, lying on the floor an alignment limestone slabs. It follows to the west a line of oblong scales and meander swastikas formed from braiding two strands, whose intervals are filled by plaited (Figs. 2, 3, 5). Midway through the corridor the pattern of the pavement

Figure 5

Mosaic of the apse of the long corridor.

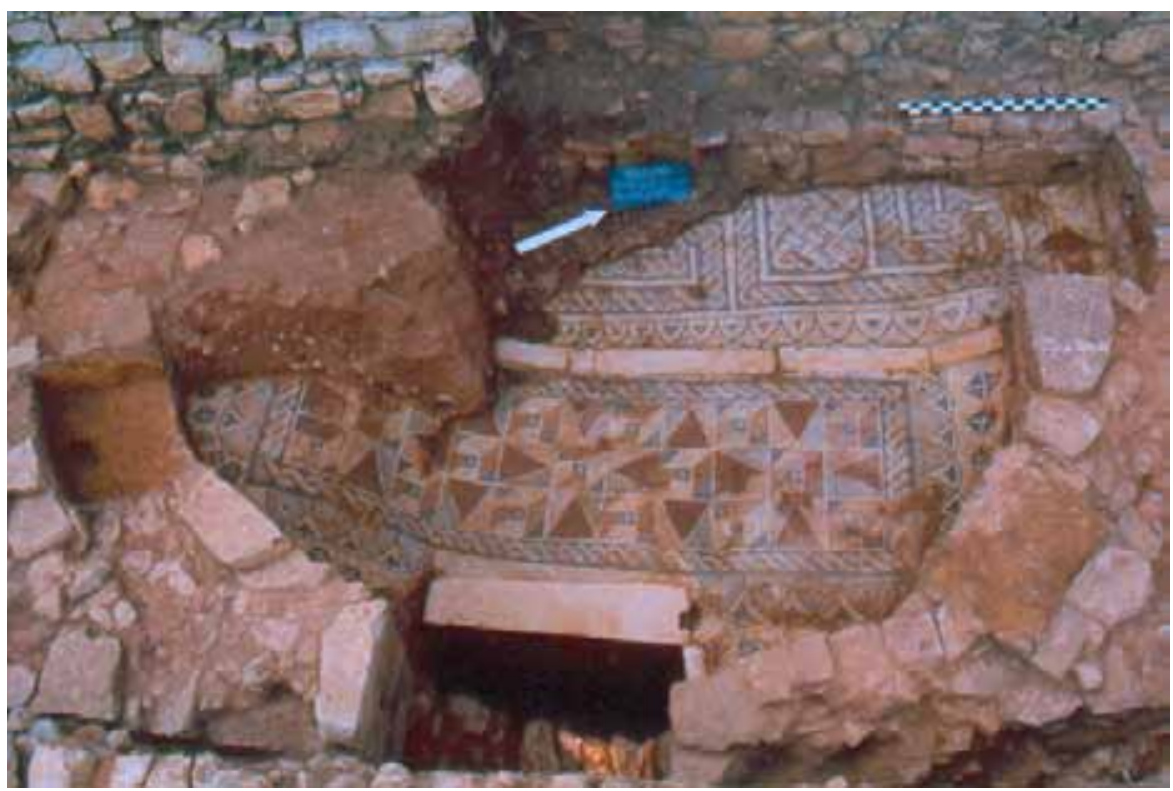




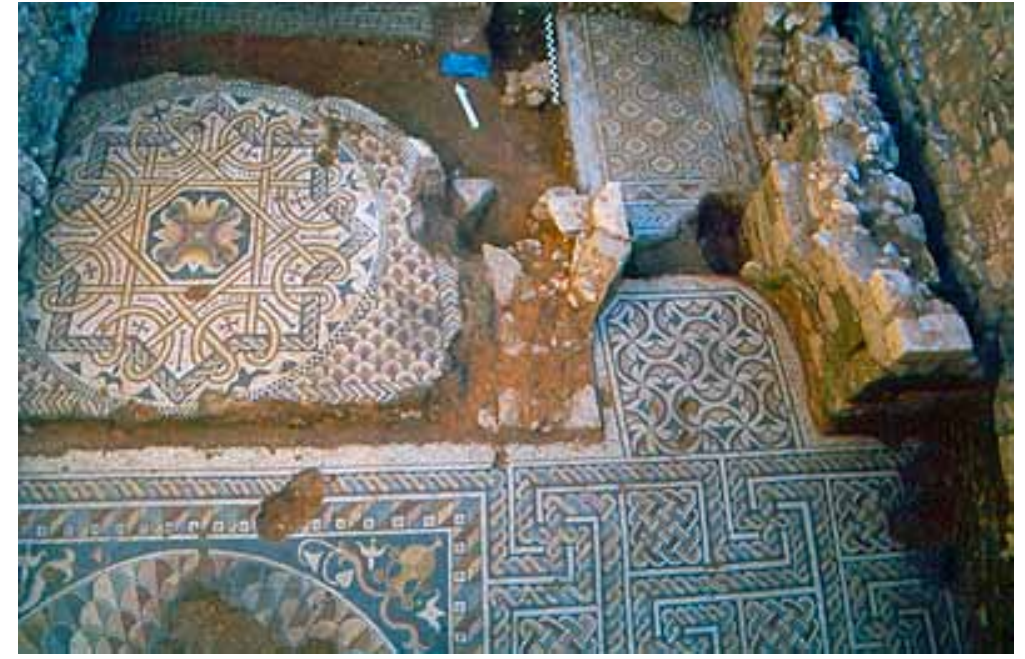

decoration will change, marking the transition to a small corridor, whose field is decorated by peltas mills with apex topped by triangular motif (Fig. 6).

At the beginning of the last third of the hall, coinciding with the alignment north / south central area of the peristyle, there are two more distinct areas of decorative pattern.

A patterned area decorates a second apse consists of a medallion with an eightpointed star, formed from a braid of two strands. Intertwined in the stems is a cable straight edges with eight nodes of Hercules, which are inscribed crosses and fleurs-de-lis (Fig. 6).

In the centre is an octagon which is decorated with a finial, formed from four cups. The frame of the medallion is a composition of adjacent scales. As the field there is a frame composition of chevrons in rainbow colours (Fig. 6).

The other zone distinct decorative pattern is decorated by a quadrangular carpet with blue background, which is inscribed a medallion formed by a composition adjacent bipartite scales (Fig. 6).

The frame the medallion, are registered in each of the four angles carpet, pitchers of which leave two floral motifs (Ivy), from cornucopias. The frame of the field is decorated with geometric figures in perspective (parallelepiped) (Fig. 6).

Material / colour: Limestone / white, blue-black, light blue, red, pink, yellow, brown.

Pavement size: 21,60 x 4,90 m

\section{Mosaic number 8 (Figures 1 and 7)}

Location: In situ. Space interpreted as cubiculum, whose pavement is visible in the northeast corner of the sixteenth-century palace. It is located at the northeast corner of the long corridor, with which it communicates through a passage.

Description: Polychrome mosaic decorated with a perimeter track where there is a play of colours, without forming any motif. The access will be found marked on the pavement by a rectangular mat with a composition of broken lines in rainbow. The field of the mosaic is decorated by peltas mills with apex topped by heart-shaped leaves, framed by a frame which is decorated by motif wave.

Material / colour: Limestone / white, blue-black, light blue, red, pink, yellow.

Pavement size: 6,00 x 4,50 m.

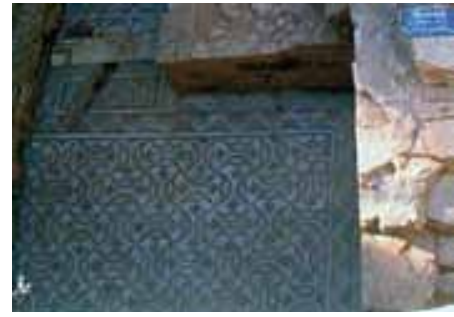

Figure 6

The long corridor mosaic and mosaic of the small corridor.

Figure 7 Mosaic of a cubiculum 


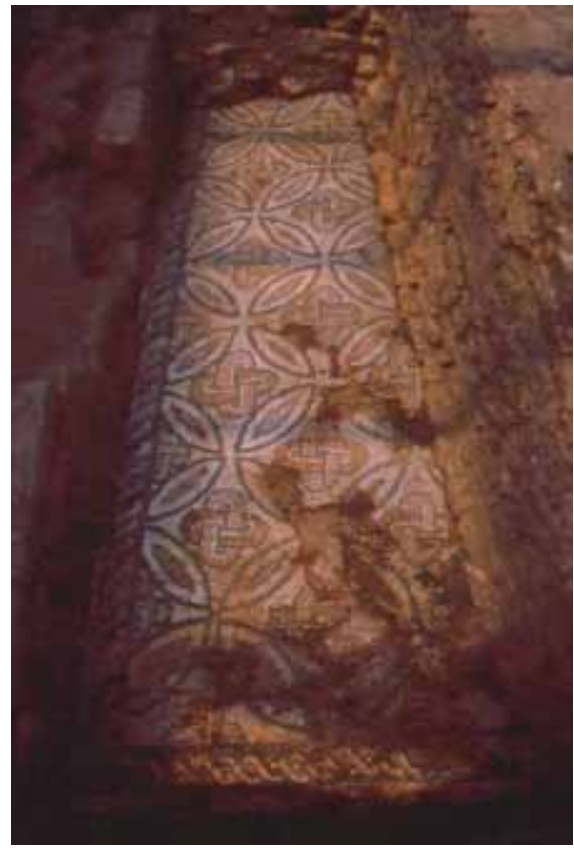

Figure 8

Mosaic of a space thermal sector.

\section{Mosaic number 9 (Figures 1 and 8)}

Location: In situ, integrated space in the area of the private roman bath building and is paved in opus tessellatum and opus signinum. Being located outside the $16^{\text {th }}$ century palace, in the northeast corner. All the pavement currently is not visible.

Description: Polychrome mosaic whose field is decorated by an orthogonal composition of intersecting circles forming quatrefoils. The spaces between these elements are filled by nodes of Solomon. The pattern of the field is framed by a border decorated by a braid of two strands.

Material / colour: Limestone / white, blue-black, light blue, red, pink, yellow.

Pavement size: $4,90 \times 3,90 \mathrm{~m}$.

\section{Mosaic number 10 (Figure 1)}

Location: In situ. Space interpreted as cubiculum, whose surface is visible in the northeast corner of the $16^{\text {th }}$ century palace.

At one time this area was become inaccessible, the only access that communicated directly with the space $\mathrm{G}$ was enclosed within walls.

Description: Bichromatic mosaic, decorated by an orthogonal composition chess.

Material / colour: Limestone / white and blue-black.

Pavement size: $3,27 \times 2,07 \mathrm{~m}$.

\section{Mosaic number 11 (Figure 1)}

Location: In situ. Space interpreted as cubiculum, with development to the exterior of the north of the $16^{\text {th }}$ century palace and therefore, the mosaic is not visible.

Description: Polychrome mosaic with a band where there is a play of colours without forming any motif. The edge of the field is formed by two strands of a braid. The field is decorated by an orthogonal composition formed by floral motifs inscribed in octagons, alternating by cruciform motifs showing motifs intertwined.

Access to space is marked in the mosaic through a rectangle whose field is decorated by linear garland of laurel leaves.

Material / colour: Limestone / white, blue-black, light blue, red, pink, yellow.

Pavement size: $3,27 \times 2,45 \mathrm{~m}$.

\section{Mosaic number 12 (Figure 1)}

Location: In situ. Space interpreted as cubiculum, with development to the north outside exterior of the $16^{\text {th }}$ century palace and therefore, the mosaic is not visible.

Description: Polychrome mosaic decorated by a band with tesserae of various colours where there is no decorative motif. The frame of the field consists of concentric squares. The carpet is completed by peltas mills and nodes of Solomon.

Material / colour: Limestone / white, blue-black, light blue, red, pink, yellow.

Pavement size: $3,85 \times 3,40 \mathrm{~m}$. 


\section{Mosaic number 13 (Figures 1 and 9)}

Location: In situ. It occupies a small corridor of the Roman building that communicates with the long corridor with development under the $16^{\text {th }}$ century palace.

Description: Polychrome mosaic decorated by a perimeter band with motif wave, which simultaneously is the frame of the field, which itself is decorated by an orthogonal composition of adjacent octagons, which are inscribed lozenges, determining square.

To mark the access that communicates with the main corridor is a rectangular mosaic carpet decorated with rainbow chevrons.

Material / colour: Limestone / white, blue-black, light blue, red, pink, yellow.

Pavement size: 5,30 x 1,60 m.

\section{Mosaic number 14 (Figures 1, 4 and 10)}

Location: In situ. Space interpreted as a support room to the triclinium.

This space is developed under the east and south sides of the $16^{\text {th }}$ century palace.

Description: polychrome mosaic decorated by a perimeter band with tesserae of various colours where there is no decorative motif except, where is the access, where is inscribed a linear composition of lozenges. The frame of the field presents a motif in wave and frames an orthogonal composition formed by peltas, by crosses, squares drawn from two strands braids, which are part florets cross, and lozenges (figure 4).

The area of the apse is decorated with a composition of scales (figure 10).

Material / colour: Limestone / white, blue-black, light blue, red, pink, yellow.

Pavement size: $8,25 \times 3,40 \mathrm{~m}$.

\section{Mosaic number 15 (Figure 1)}

Location: In situ. We found only some traces of the triclinium mosaic on a pavement built in opus signinum. This mosaic was polychrome. The overlap of the two floors can be explained by a reformulation that this Roman building space has undergone a given time. This space is developed in the southeast corner of the courtyard of the $16^{\text {th }}$ century palace (space $\mathrm{M}$ ).

Dimensions of space: $6,50 \times 5,30 \mathrm{~m}$.

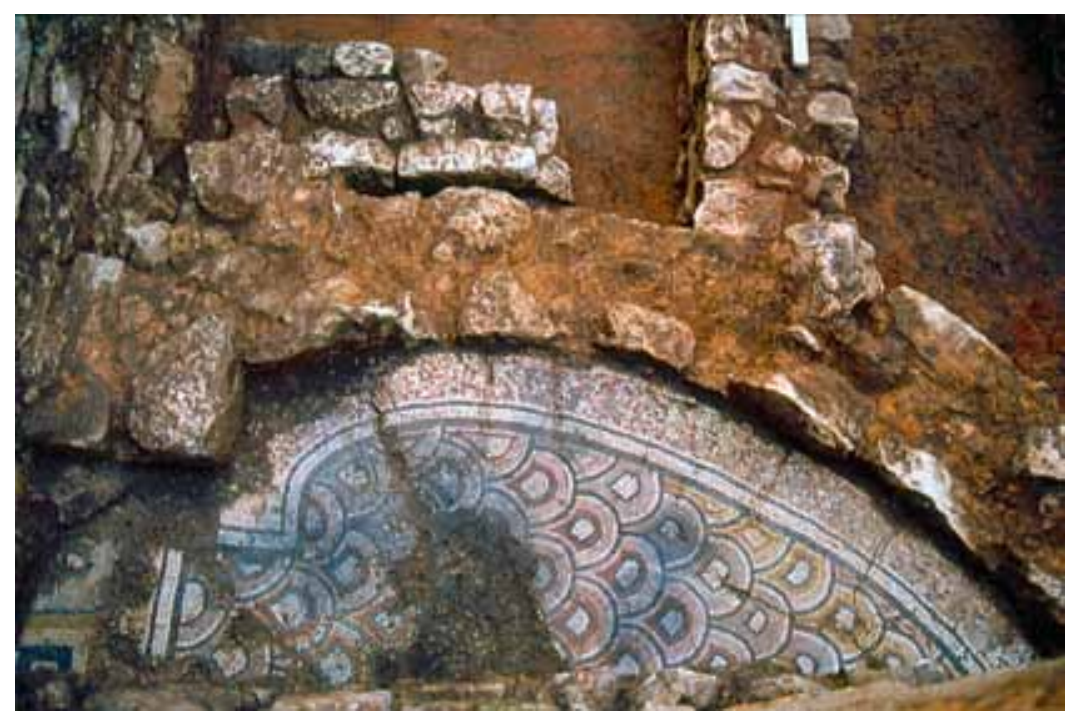

Figure 10

Mosaic of the apse of the support room to triclinium 


\section{Mosaic number 16 (Figures 1 and 12)}

Location: In situ. Space that should have had a social function, as a reception room of the Roman building (exedra). Comes up located at the northwest corner of the peristyle and is visible in the west side of the $16^{\text {th }}$ century palace, where it currently works the reception of visitors.

Description: Polychrome mosaic that occupies one of two areas that space and are separated by a structure where are located three access that defines at the north and south.

The mosaic in question decorates the floor of the north area. To mark the access which lies further west, it is drawn a small rectangular mat formed by an orthogonal composition of concentric squares.

On the west side of the mosaic, between the perimeter band and the edge of the field, it is a second carpet, rectangular and larger, which is part of a composition broken lines in rainbow.

The frame of the field is decorated by a band with two entwined cable straight edges. This appears to frame an orthogonal composition crosses, decorated in the centre with finials, with the stems, inscribed with chevrons in rainbow, and octagons of concave sides, formed from braiding two strands, which are inscribed concentric circles and eight-pointed stars formed by two interlocking squares.

Material / colour: Limestone / white, blue-black, light blue, red, pink, yellow.

Pavement size: 8,70 x $6,10 \mathrm{~m}$.

\section{Mosaic number 17 (Figures 1 and 11)}

Location: In situ. Space interpreted as cubiculum abutting the northwest corner of the long corridor with development to the exterior north of the $16^{\text {th }}$ century palace where it is visible.

Description: Polychrome mosaic decorated with a carpet with rainbow chevrons in the access that communicates with the long corridor. This is framed to the south and to the north by a decorative pattern formed by lozenges alignments.

In the southwest and southeast corners of the compartment are two carpets. The first larger, whose field comes decorated with scales. In the other, the field is decorated by an orthogonal composition of squares and concentric rectangles. They are still visible bands of the east side and the west side of mosaic. Both with a composition of rainbow in broken lines.

Figure 11

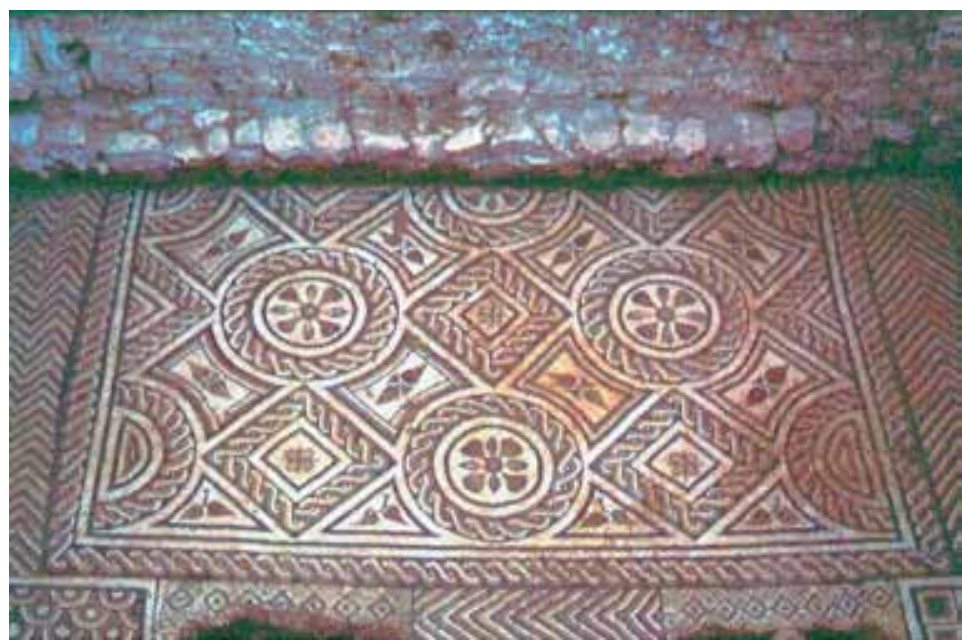




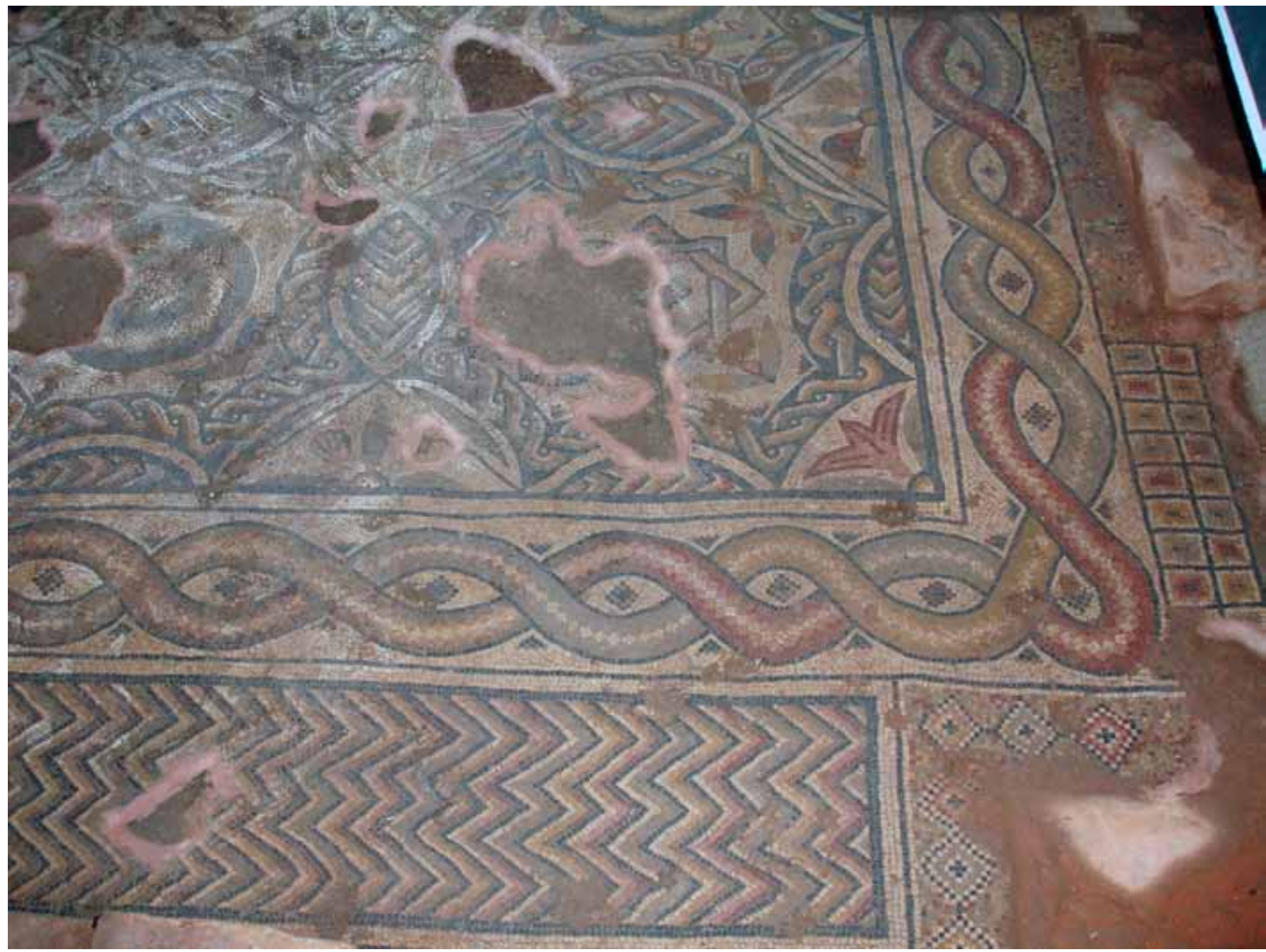

The edge of the field is decorated by a braid of two strands. In the centre is an orthogonal composition with circles and squares drawn from braid two strands, which fall floral motifs. The spaces of the composition are filled with triangles and rectangles with sides concave with plant motifs.

Material / colour: Limestone / white, blue-black, light blue, red, pink, yellow.

Figure 12

Mosaic of the north area of the space that should have had a social function, as reception room of the Roman building.

Pavement size: 4,50 x 3,36 m.

\section{Mosaic number 18 (Figures 1,13 and 14)}

Location: In situ. Space that should have had a social function, as reception room of the Roman building (exedra). This abuts the northwest corner of the peristyle and is visible in the west side of the $16^{\text {th }}$ century palace, where currently works the reception of visitors. Part of the pavement is exposed like a panel.

Description: Polychrome mosaic that occupies one of two areas of that space and are separated by a structure where are located three access. In the mosaic that is located on the south side $^{2}$ there is an apse which is decorated by an orthogonal composition with concentric squares.

2 The mosaic was raised from its original location in 2004 and restored in Conímbriga archaeology workshops, currently lying exposed as panel at one of the walls of the space where he currently works the reception of visitors of the Monumental Complex of Santiago of Guarda, close to the original location where it was. 


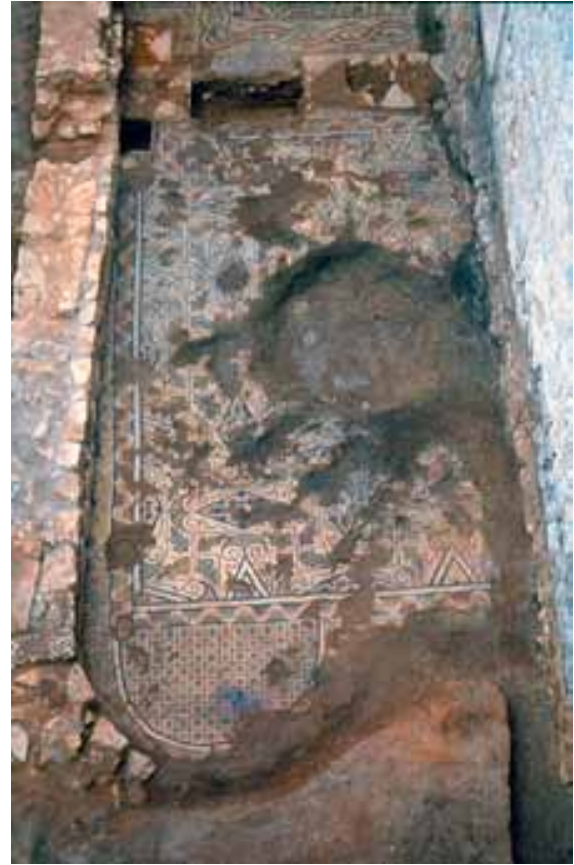

Figure 13

Mosaic of the south area of the space that should have had a social function, as reception room of the Roman building.

Figure 14

Mosaic exposed as panel at one of the walls of the space where he currently works the reception of visitors of the Monumental Complex of Santiago of Guarda.

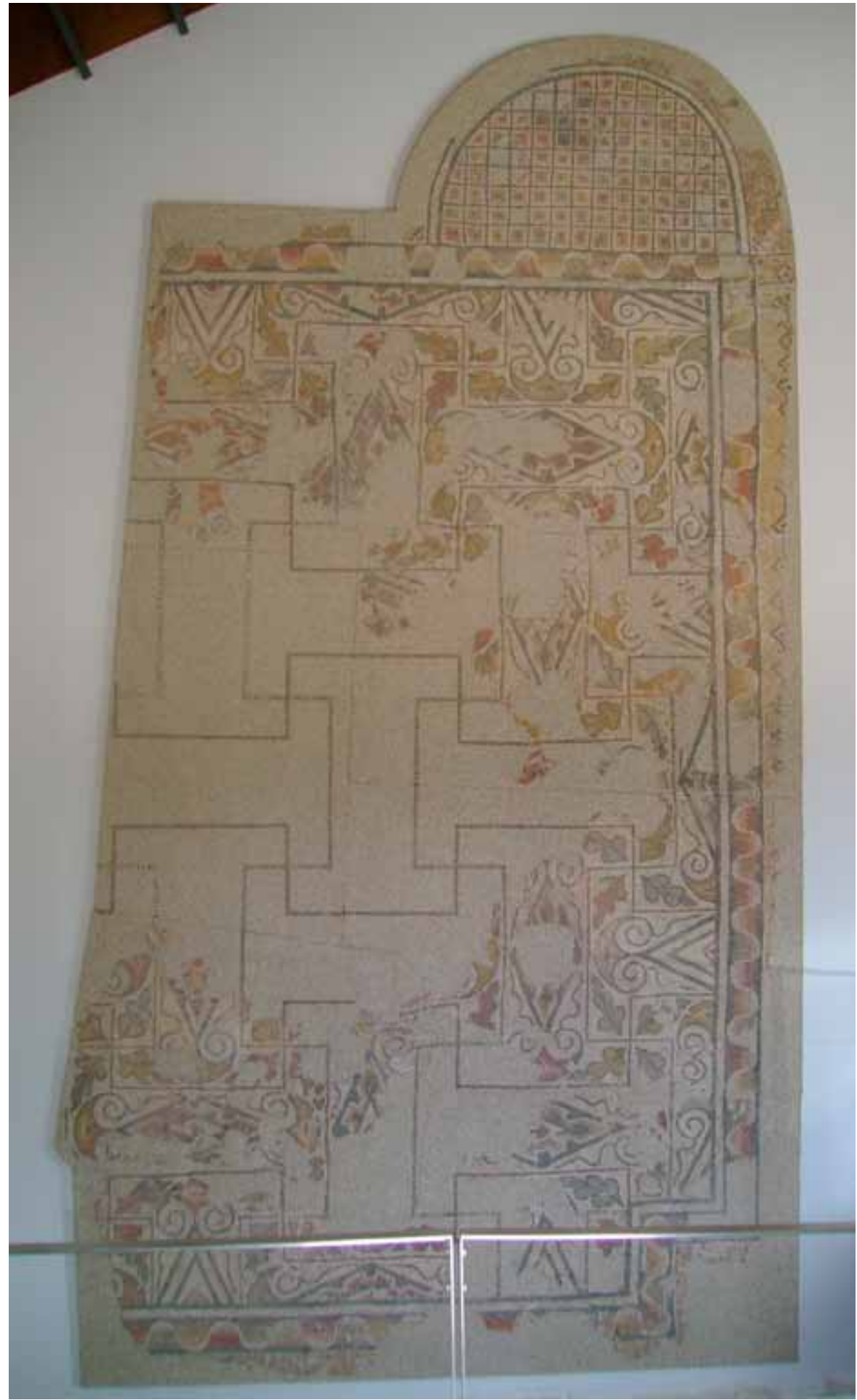

The band of the mosaic is decorated by a colour match, being inscribed along the western edge of the mosaic one lozenges alignment.

As the field frame there is a motif to wave to circumscribe the field. This in turn is decorated by a meander of keys (Meander swastikas drawn in a certain way), by lozenges for peltas with internal spirals at each end and for motifs of vegetable nature, the oak leaf.

Material / colour: Limestone / white, blue-black, light blue, red, pink, yellow.

Pavement size: 9,15 x 5,60 m. 


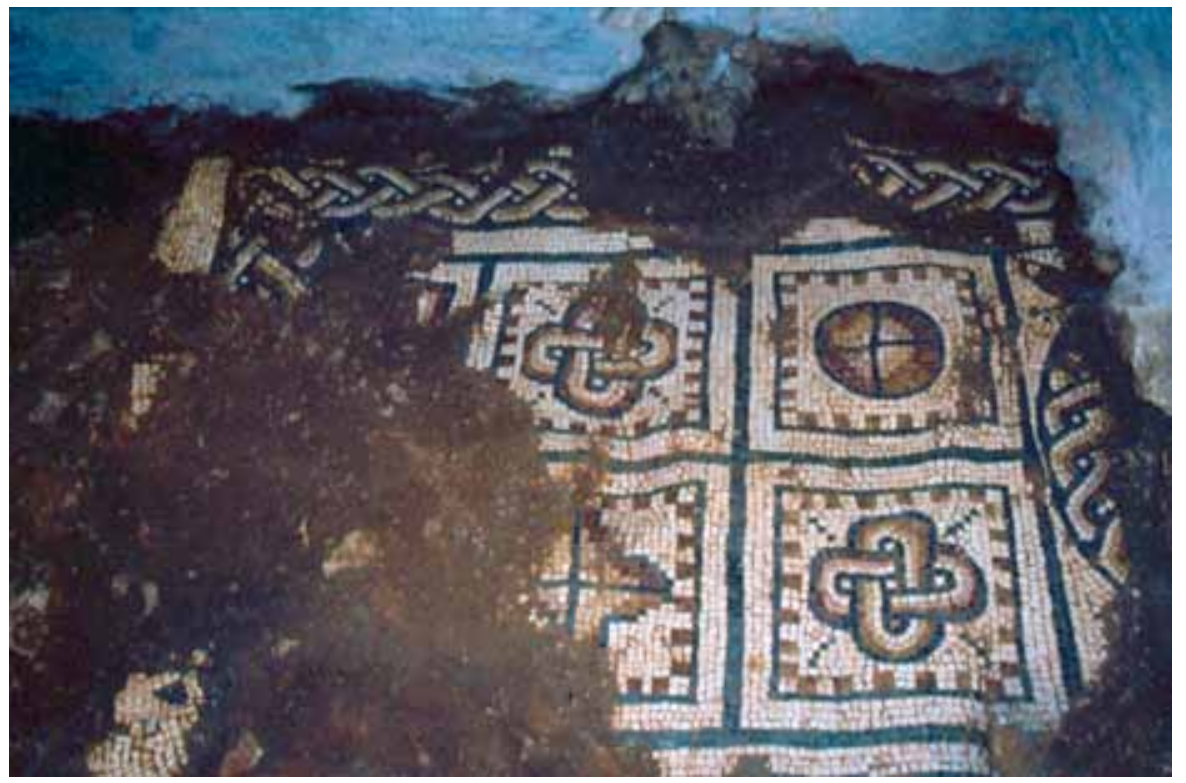

\section{Mosaic number 19 (Figures 1 and 15)}

Location: Mosaic fragment that decorate the apse of one space interpreted as another support room to the triclinium.

Currently it is exposed in one of the multipurpose rooms of the Monumental Complex of Santiago da Guarda.

The space of the Roman building where originally was found the mosaic develops under the south side and the courtyard of the $16^{\text {th }}$ century palace.

Description: Polychrome mosaic decorated in the field by an orthogonal composition formed from four squares, which are inscribed nodes of Solomon, a circle and lozenges, whereas the pattern of the edge there is a braid of with three strands.

Material / colour: Limestone / white, blue-black, light blue, red, pink, yellow.

Dimensions of space: $7,80 \times 3,70 \mathrm{~m}$.

\section{Mosaic number 20 (Figure 1)}

Location: A small bichromatic fragment in situ of about $10 \mathrm{~cm}$ per side, which may be related to a reformulation that the Roman building has undergone a given time. Now this fragment is in the east side of the $16^{\text {th }}$ century palace, in the room that communicates with the chapel (space $\mathrm{N}$ ).

\section{Mosaic number 21 (Figure 1)}

Location: Discovered in 2012, during the redevelopment of the surrounding monument. The mosaic in question is in situ, under a contemporary structure of the $16^{\text {th }}$ century palace, demarcating this a space that was paved with irregularly limestones that existed around the residence.

The archaeological investigation had allowed to observe an alignment of a row of tesserae of various colours with about $2 \mathrm{~m}$ in length.

The space paved with the coating in question belongs to the private area of the Roman building identified as the thermal bath (space U). 


\section{Chronology of mosaic art of the urban area from the Roman villa of the Monumental Complex of Santiago da Guarda}

The pattern of mosaics from the Roman villa of Santiago da Guarda, are similar to the decoration used in the villae of the late 4th century, and the early 5th century, in the Iberian Peninsula, where there are several parallels presented by several studies on the theme.

Also in the mosaic art of the Roman villa of Santiago da Guarda is present the geometrism main, decorative type of that period, with a great profusion of decorative elements, this is the "Horror Vacui" characteristic of the Lower Empire (Blazquez 1993: 48, 66, 120).

\section{Bibliography - Kaynaklar}

Alarcão 1988

Alarcão 1988

Alarcão 1999

Alarcão 2004

APECMA 2015

Blazquez 1993

Brown 1967

Caetano 2001

Correia 2005

Correia 2013

Cortesão - Pereira - Trindade 2006

L. Cortesão - R. M. M. Pereira - L. Trindade, "Um sedimento, uma ruína, um projecto: o Paço dos Vasconcelos, em Santiago da Guarda", Monumentos, Lisboa, DGEMN 25, 214-225.

Cortesão - Pereira 2015

Coutinho 1986

Ferri 1960

Gorges 1979

Gros 2001

Irujo 2004

Lancha - André 1994

J. de Alarcão, Roman Portugal, Warminster, Aris-Phillips Ltd. II, fasc. 2.

J. de Alarcão, O Domínio Romano em Portugal. Mem Martins:Publicações Europa-América.

J. de Alarcão, Conimbriga, O Chão Escutado, Circulo de Leitores.

J. de Alarcão, "Introdução ao Estudo da TecnologiaRomana", Cadernos de Arqueologia e Arte, Fac. de Letras, Instituto de Arqueologia, Coimbra.

APECMA 2015, Mosaicos Romanos. Fragmentos de Cultura nas proximidades do Atlântico. Actas do Encontro Portugal - Galiza.

J. M. Blazquez, Mosaicos Romanos de Espana, Cátedra.

F. E. Brown, Roman Architecture, New York.

M. T. Caetano, "Mosaicos Romanos de Lisboa", Conimbriga XL, 65-82.

L. N. C. Correia, Decoração Vegetalista nos Mosaicos Portugueses. Instituto de História de Arte, FCSH-UNL, Edições Colibri, Lisboa.

V. H. Correia, A Arquitectura Doméstica de Conímbriga e as Estruturas Económicas e Sociais da Cidade, Coimbra.

L. Cortesão - R. M. M. Pereira, "Um sedimento, uma ruína, um projecto: o Paço dos Vasconcelos em Santiago da Guarda”. IV Congresso Internacional: Casa Nobre-Um Património para o Futuro. Arcos de Valdevez.

J. E. R. Coutinho, Ansião, Perspectiva Global da Arqueologia, História e Arte da Vila e do Concelho, Coimbra.

S. Ferri, Vitrúvio (Dai Libri I-VII), Recensione del texto traduzione e note.

J. G. Gorges, Les Villas Hispano-Romaines, Inventaire et Problématique archéologiques, Publications du Centre Pierre Paris.

P. Gros, "Maisons, Palais, Villas et Tombeaux", Architecture Romaine, vol. 2. Paris, Picard.

M. A. M. Irujo, "Los mosaicos de la villa romana de Liédna (Navarra)", Trabalhos de Arqueologia Navarra 17, Pamplona.

J. Lancha - P. André, "De la Trace à la Restitution des Mosaiques in situ: La Mosaique aux Etóiles de la Villa de Torre de Palma", Mosaicos V - Conservation, Protection and Presentation, Conimbriga, ICCM, 169-176.

Monteiro - D’encarnação 1993/94

A. J. N. Monteiro - J. D’encarnação, "A propósito de uma inscrição latina, em Santiago da Guarda, Ansião", Conimbriga, XXXII-XXXIII, 303-311.

Oleiro 1992

J. M. B. Oleiro, Conímbriga. Casa dos Repuxos. Corpus dos Mosaicos Romanos de Portugal, Conventus Scallabitanus I, Conímbriga.

Oliveira 2003 
C. F. Oliveira, Mosaicos Romanos de Portugal e Algarve Oriental, Dissertação de Doutoramento em História, Coimbra, FLUC.

Pereira 2002

R. M. M. Pereira, Prospecção Arqueológica do Concelho de Ansião-Relatório de Progresso, IPA, Texto policopiado.

Pereira 2002

R. M. M. Pereira, Intervenção Arqueológica no Paço dos Vasconcelos, Relatório de Progresso Técnico e Científico (IASG), Texto policopiado.

Pereira 2003

R. M. M. Pereira, 2003 Intervenção Arqueológica no Paço dos Vasconcelos. Relatório de Progresso Técnico e Científico (IASG), Texto policopiado.

Pereira 2004

R. M. M. Pereira, Intervenção Arqueológica no Paço dos Vasconcelos. Relatório de Progresso Técnico e Científico (IASG), Texto policopiado.

Pereira 2005 R. M. M. Pereira, Intervenção Arqueológica no Paço dos Vasconcelos, Relatório de Progresso Técnico e Científico (IASG), Texto policopiado.

Pereira 2006

R. M. M. Pereira, Intervenção Arqueológica no Paço dos Vasconcelos, Relatório Final Técnico e Científico (IASG), Texto policopiado.

Pereira 2008

R. M. M. Pereira, "Resultados dos Trabalhos Arqueológicos no Paço dos Vasconcelos, Maio de 2002 a Julho de 2004", Actas do IV Congresso de Arqueologia Peninsular, Hispania Romana, Centro de Estudos de Património, Dep. de História, Arqueologia e Património, Universidade do Algarve. Faro. 10, 171-181.

Pereira 2008

R. M. M. Pereira, "A Residência Senhorial dos Condes de Castelo Melhor e a Villa Romana de Santiago da Guarda", Actas do IV Colóquio Internacional de Arqueologia, Las Villae Tardorromanas en el occidente del Imperio: arquitectura y función. Gijón, Ediciones Trea.

Pereira 2008 R. M. M. Pereira, “A intervenção Arqueológica no Paço dos Vasconcelos, Santiago da Guarda”, Al-Madan. Centro de Arqueologia de Almada. II ${ }^{\mathrm{a}}$ série.16, 162-163.

Pereira 2011 R. M. M. Pereira, Contributo para Elaboração da Carta do Património Arqueológico do Concelho de Ansião. Fase de Caracterização do Processo de Revisão do PDM, Texto policopiado.

Pereira 2011

R. M. M. Pereira, "Resultados dos Trabalhos Arqueológicos no Paço dos Vasconcelos, (Maio de 2002 a Agosto de 2005)", Actas do X Colóquio da Associação Internacional para o Estudo dos Mosaicos Antigos (AIEMA), Conímbriga, 849-859.

Percival 1976

J. Percival, The Roman Villa, BT. Batsford LTD, London.

Pessoa 1998 M. Pessoa, Villa Romana do Rabaçal, Um Objecto de arte na paisagem, Penela, Câmara Municipal.

Ráfols 1952

S. Ráfols, La Villa Romana De La Dehesa De La Cocosa, Badajoz, R.E.E., Anejo 2.

Revista Da História Da Arte 2008

Revista Da História Da Arte, O Mosaico na Antiguidade Tardia, Instituto da História da Arte. Fac. C. S. H. Universidade Nova de Lisboa, N. ${ }^{\circ}$ 6. Edição, Instituto de História da Arte.

Alarcão - Cunha - Paiva 1996

A. Alarcão - L. Cunha - J. Paiva, O Oppidum de Conimbriga e as Terras de Sicó: Roteiro, Liga de Amigos de Conimbriga.

Saa 1959

M. Saa, As Gandes Vias Da Lusitânia, II, Lisboa.

Trindade 2001

L. Trindade, O Paço dos Vasconcelos, DGEMN.

Viegas - Abraços - Macedo 1993

C. Viegas - F. Abraços - M. Macedo, Dicionário de Motivos Geométricos no Mosaico Romano, Conímbriga. 